\title{
LOGIKA WUJUD ȘADRA MERETAS NALAR RADIKALISME BERAGAMA
}

\author{
Ulya \\ Sekolah Tinggi Agama Islam Negeri (STAIN) Kudus \\ e-mail: ulya.kamera@gmail.com
}

\begin{abstract}
Its uniqueness lies in his ability to articulate the various traditions of thoughts that grew and developed rapidly in Persia, the land of his birth. The traditions were peripatetic, illuminative, gnostic, and theological tradition of Islam. It has necessitated Persia as a heterogeneous region. This heterogeneity, to some extent, can susceptibly bring conflict i.e., physical violence from hurting to even casting innocent human life. Indeed, the thought of Sadra was born within the era of a deep reflection process responding to the socio-cultural sphere. Also, it answered the issues that emerged at that time i.e., how the heterogeneous condition did not lead to intolerance, violence, and even acts of terror, instead created a safe, peace, and harmonious atmosphere. By his thought, Sadra did something very valuable to solve the problems in the country. Sadra's thought is built up by and inherent with his basic idea, fundamental and logical structure of transcendence which are relevant to be socialized in a plural and heterogeneous society in which conflict and violence are vulnerable. Socialization of logica structure is relevant for attitudes and behaviors of people since they do not appear suddenly, yet are formed due to reason or logic or way of thinking. Thus, the study of the classical intellectual treasures potentially provides a meaningful contribution to be a basic solution for similar problems existing in nowadays.
\end{abstract}

\begin{abstract}
Abstrak: Sadra adalah seorang filosof yang produk pemikirannya tergolong unik. Keunikannya terletak pada kepiawaiannya mendialogkan antar berbagai tradisi pemikiran yang tumbuh dan berkembang pesat di Persia, tanah kelahirannya. Tradisi pemikiran dimaksud adalah tradisi paripatetik, tradisi illuminatif, tradisi gnosis, dan tradisi teologi Islam. Hal ini telah meniscayakan Persia menjadi sebuah wilayah yang heterogen. Heterogenitas rentan memunculkan konflik sampai aksi kekerasan fisik yang seringkali melukai, bahkan melayangkan jiwa manusia tak berdosa. Sesungguhnya pemikiran Sadra lahir sebagai anak zaman dari sebuah proses refleksi mendalam, merespon kondisi sosial-kultural, menjawab persoalan yang berkembang saat itu: bagaimana agar sebuah kondisi yang heterogen tidak melahirkan intoleransi, kekerasan, bahkan aksi-aksi teror, tetapi justru tercipta suasana aman, damai, dan harmonis. Dari pemikiran wujudnya, Sadra melakukan sesuatu yang sangat berharga di negerinya dalam rangka memecahkan persoalan tersebut. Dalam pemikiran wujudnya ini terbangun dan inheren di dalamnya ide dasar, struktur fundamental, struktur logika transendensi yang relevan untuk disosialisasikan dalam masyarakat berbasis plural dan heterogen yang rentan konflik dan kekerasan tersebut. Sosialisasi struktur logika tersebut relevan karena sikap dan perilaku seseorang tidaklah muncul secara tiba-tiba tetapi terbentuk berkat nalar atau logika atau
\end{abstract}


cara berpikir yang dimilikinya. Dari sini maka kajian terhadap khasanah intelektual masa lalu berpeluang bermakna dan bisa memberikan kontribusinya bagi dasar solusi permasalahan senada yang ada pada saat sekarang ini.

Keywords: struktur logika; konsepsi wujud; Șadra; radikalisme

\section{A. Pendahuluan}

Tindakan radikal, aksi teror, konflik dan kekerasan lainnya telah menghantui hampir di seluruh belahan dunia, termasuk Indonesia. Masih hangat dalam ingatan peristiwa di awal tahun ini, tepatnya pada tanggal 14 Januari 2016, telah terjadi aksi bom bunuh diri di Jl. MH. Thamrin, tepatnya di depan Gedung Sarinah dan Kedai Kopi Starbucks. Peristiwa itu telah menewaskan 7 (tujuh) orang tidak berdosa dan puluhan orang lainnya terluka. Kasus serupa juga pernah terjadi pada tahun sebelumnya di pusat perdagangan ITC Depok, pernah pula terjadi di depan kedutaan Australia, dan seterusnya. Tidak hanya di Indonesia, deretan peristiwa radikal dan teror yang mengatasnamakan agama juga terjadi di mana-mana.

Secara umum bahwa cikal bakal lahirnya tindakan ini adalah karena ketidakpuasan terhadap kondisi politik, ekonomi, sosial, dan lain-lain. Dalam melampiaskan rasa kejengkelannya, mereka merepresentasikannya dengan sikap intoleran, tidak sudi menghargai pendapat atau keyakinan pihak lain, dan bersikap revolusioner, yakni cenderung menggunakan kekerasan untuk mencapai tujuan.

Sikap intoleran merupakan wujud sistem berpikir eksklusif, yakni cara pikir yang lebih mengedepankan truth claim. Kelompok saya yang paling benar, pendapat saya yang paling baik, agama dan keyakinan saya yang paling menyelamatkan. Sedangkan yang lain adalah salah, tidak baik, dan merugi. Nalar atau logika semacam ini menjadi bermasalah jika telah merambah di ruangruang publik yang serba heterogen, yang di dalamnya hidup dan berkembang beragam keyakinan, agama, ras dan warna kulit, suku bangsa, bahasa, dan seterusnya. Di sinilah perlu logika berpikir yang responsif, relevan, dan adekuat di tengah kondisi semacam itu sehingga heterogenitas tidak memicu munculnya konflik dan kekerasan.

Șadra atau lebih dikenal dengan Mulla Șadra adalah salah satu filosof Persia, yang hidup pada masa kerajaan Syafawi. Dalam wilayah kerajaan itu hidup bersama-sama dan saling berdampingan beragam tradisi intelektual. Ada 
paripatetisme yang lebih menekankan akal, gnosisisme/mistisisme yang lebih mengedepankan intuisi, syi'isme yang lebih berpedoman pada teks, dan illuminasionisme yang memadukan antara akal dan intuisi. Setting keragaman ini mengilhami kreativitas Șadra menciptakan suatu nalar atau logika atau cara berpikir yang sama sekali baru, yang bersifat mentransendensi cara berpikir dari beragam tradisi intelektual yang telah ada sebelumnya. Cara pikir transendensi ini mestinya akan meretas sekat-sekat eksklusivisme dari masingmasing tradisi intelektual menuju sebuah cara pikir dan sikap yang mengatasi, dialogis, terbuka, toleran, dan saling menghargai tradisi, pendapat, keyakinan pihak lain.

Membaca dan menyosialisasikan nalar atau logika atau cara pikir dari pemikiran Șadra ini di tengah-tengah masyarakat diharapkan bisa meminimalisasi aksi-aksi radikal dan teror yang sering terjadi saat ini. Dan artikel sederhana ini akan memulai dengan mendeskripsikannya secara berturut-turut, yaitu: potret hidup Șadra yang akan menginformasikan secara memadai tentang perjalanan hidupnya dan latar belakang sosial yang melingkupinya yang pastinya akan mempengaruhi produk pemikirannya; kemudian menjelaskan detail tentang pemikiran konsep wujudnya, yang dari sini akan ditelisik struktur logika transendensi yang ada di baliknya, dan yang terakhir akan diurai implikasi dan relevansi struktur logika tersebut untuk sebuah masyarakat yang di dalamnya hidup beragam keyakinan dan agama khususnya.

\section{B. Biografi dan Setting Sosio Kultural Kehidupannya}

Seorang filosof dari Negeri Persia, Șadra, memiliki nama lengkap Muhammad ibn Ibrāhīm al-Qawāmī al-Shirāzì atau biasa dipanggil dengan Mulla Șadra. Dia dilahirkan di kota Syiraz, pada tahun 979H/1571M. ${ }^{1}$ Ayahnya

\footnotetext{
${ }^{1}$ Menurut Syaifan Nur bahwa berdasarkan sumber-sumber tradisional tentang tahun kelahiran Sadra tidaklah diketahui secara pasti, dan baru diketahui tatkala Thabataba'i melakukan koreksi terhadap edisi baru buku Hikmah Muta'āliyah dan mempersiapkan penerbitannya. Pada catatan pinggir yang ditulis oleh pengarangnya sendiri, ketika dia membicarakan tentang kesatuan antara subjek yang berpikir dan obyek pemikiran (ittihād al-āqil bi al-ma'qūl) ditemukan kalimat sebagai berikut: "Aku memperoleh inspirasi ini pada saat matahari terbit di hari Jum'at, tanggal 7 Jumādī al-'Ulā 1037H/14 Januari 1628M, ketika itu usiaku telah mencapai 58 tahun". Sejak itu sumber-sumber mengkonfirmasikan informasi tersebut. Akan tetapi karena tidak mungkin diketahui apakah 58 tahun itu menunjuk genap 58 tahun ataukah kurang sedikit maka tahun kelahirannya tidak ditetapkan secara pasti selain menunjuk di antara tahun 979 dan 980H atau 1571 dan 1572M. Syaifan Nur, Filsafat Wujud Mulla Șadra (Yogyakarta: Pustaka Pelajar, 2002), h. 43.
} 
bernama Ibrāhīm Ibn. Yahyyā al-Qawāmī al-Shirāzī, seorang mantan gubernur di Provinsi Fars. $^{2}$

Oleh sebagian pemerhati filsafat, Șadra dipandang sebagai figur yang sangat berperan dalam menghidupkan kembali filsafat di dunia Islam setelah al-Gazālī. Hal ini karena keunikan dan orisinalitas corak filsafatnya. Dengan mengintegrasikan seluruh ide penting filsafat yang telah dikembangkan oleh para pendahulunya, dia membentuk dan menguraikannya menjadi sesuatu yang sama sekali baru.

Șadra dilahirkan di tengah-tengah masa pemerintahan dinasti Syafawiyah (907-1145H/1501-1732M). ${ }^{3}$ Dinasti ini mendirikan kerajaan yang bernama kerajaan Syafawi. Kerajaan ini memiliki keunikan sejarah dipandang dari sudut kehidupan intelektualnya. Di sana hidup beraneka ragam tradisi intelektual, mulai kebangkitan kembali filsafat paripatetisme akibat pengaruh ' $a q{ }^{4}$ Yunani, yang bersifat 'aql al-kawnī, kemudian berkembang pula tradisi gnosisismemistisisme atau 'irfäniyyah yang merupakan pengaruh tradisi Persia kuno, ${ }^{6}$ dan trend teosofi-illuminasionisme atau ishrāqiyyah sebagai perkembangan intelektual baru hasil perpaduan menarik antara filsafat paripatetik dan tradisi gnosis, ${ }^{7}$ dan teologi Islam atau kalämiyyah yang merupakan produk nalar Arab, yakni 'aql al-mukawwin. ${ }^{8}$ Dengan akar sejarah yang melingkupi dinasti Syafawi seperti itu nantinya akan membentuk karakteristik intelektual khas di Persia, yang sering disebut dengan mazhab Isfahan sebagaimana diintroduksi oleh Șadra.

\footnotetext{
2S. Hossein Nasr, "Sadr al-Din Shirazi (Mulla Sadra)" dalam MM Syarif (ed.), History of Muslim Philosophy (Weisbaden: OttoHarrasowitz, 1963), h. 932-933.

${ }^{3}$ Istilah Syafawi menunjuk pada nama salah satu dinasti di Persia. Dinasti ini merupakan sebuah restorasi yang berperan penting di imperium Persia dan sekitarnya bagi rekonstruksi rasionalitas setelah mengalami kemerosotan selama lebih dari delapan setengah abad. Syaifan Nur, "Tradisi Intelektual di Kawasan Persia: Melacak Setting Historis Pemikiran Mulla Șadra" dalam Esensia, vol.3, no.1 (Januari 2002), h. 85.

4'Aql dalam bahasa Muhammad 'Ābid al-Jābirī sama dengan $f i k r$, yang bermakna nalar dalam arti ideologi. Muhammad 'Ābid al-Jābiri, Takwīn al-'Aql al-'Arabī (Beirut: al-Markaz al-Ṣaqafí al-'Arabī, 1991), h. 11.

5Ibid., h. 18.

${ }^{6}$ S. Nomanul Haq, "The Indian and Persian Background" dalam S. Hossein Nasr dan Oliver Leaman (ed.), History of Islamic Philosohpy, Part I (London and New York: Routledge, 1996), h. 59.

${ }^{7}$ Hossein Ziai, "Shihab al-Din Suhrawardi: The Founder of The Illmuninasionist School" dalam Ibid., h. 444.

8 Muhammad 'Ābid al-Jābiri, Takwīn..., h. 15, 134-135.
} 
Tentang masa muda Șadra, seperti anak-anak Islam lainnya, dia menghabiskan waktunya untuk mempelajari sumber ajaran Islam yaitu al-Qur'an dan Hadis, serta belajar bahasa, yaitu bahasa Arab dan bahasa Persia. Sebagai anak cerdas, dia mampu dengan cepat menyerap seluruh yang diajarkan padanya sehingga pada masa ini oleh masyarakat, Șadra sudah dikenal mempunyai tingkat intelegensi dan kesalehan yang tinggi.

Merasa masih kurang dengan ilmu yang telah diperolehnya masa itu, Șadra melanglang ke kota lain. Kota yang menjadi tujuannya adalah Isfahan. Dipilih Isfahan karena kota ini menjadi jantung keilmuan yang amat penting, baik dalam ilmu-ilmu intelektual (intellectual sciences) maupun ilmu-ilmu keagamaan (transmitted sciences), di samping latar belakang iklim pendidikan dan kehidupan masyarakatnya berada dalam matrik Syiah.

Di Isfahan, Șadra berguru kepada ulama-ulama terkemuka, utamanya, Shaykh Bahā' ad-Dīn al-Amilīy (w. 1031H/1622M), seorang pakar hukum Syiah, dan Shaykh Muḥammad Bāqir Astrabadīy atau yang lebih dikenal dengan Mir Damad (w. 1041H/1631M), ${ }^{9}$ yang keduanya sangat berpengaruh terhadap perjalanan dan produk intelektualnya. Șadra berguru kepada al-Amilīy untuk belajar secara luas ilmu-ilmu agama. Sedangkan pada Mir Damad, dia belajar ilmu-ilmu rasional dan dasar-dasar kefilsafatan yang nantinya menjadi salah satu unsur dalam keseluruhan struktur bangun filsafatnya. ${ }^{10}$

Dari Isfahan, dia melanjutkan rihlah 'ilmiyyah-nya ke Kahak, sebuah kampung kecil di dekat Qum. Sudah sejak lama, Șadra mengidam-idamkan tinggal di sana, tempat suci orang-orang Persia. Tempat ini terkenal indah

${ }^{9}$ Mir Damad adalah guru sangat dihormati dan dijunjung tinggi oleh Șadra. Muhammad Tahir Tunikabuni, penulis kamus biografi Qașaș al-Ulamā', melaporkan bahwa pada suatu hari ketika Mulla Șadra masih menjadi murid Mir Damad, dia sedang menunggu gurunya masuk kelas untuk memulai diskusi. Tiba-tiba pintu terbuka dan datanglah seorang pedagang lokal dari Isfahan yang akan bertanya kepada gurunya, Mir Damad, itu. Sementara mereka berdua saja yang berada dalam satu kelas/ ruangan, pedagang tersebut bertanya kepada Șadra: "Apakah Mir Damad seorang yang lebih unggul dalam pembelajarannya bagi seorang ulama terkemuka di Isfahan?". Șadra menjawab: "Mir lebih unggul". Pedagang itu menelusuri lebih jauh: "Bagaimana dengan ibn. Sina? Apakah dia berbanding dengan master paripatetik itu?" Șadra menjawab: "Mir lebih unggul”. Pedagang itu bertanya lagi: " Bagaimana dengan ibn Sina, sang guru kedua setelah Aristoteles?" Șadra tertegun sejenak: "Jangan takut". Mir Damad mendorong muridnya dari ruang yang berdekatan: "Katakan padanya, Mir lebih unggul". Hamid Dabashi, "Mir Damad and The Founding of The School of Isfahan" dalam S. Hossein Nasr dan Oliver Leaman (ed.), History..., h. 602.

${ }^{10}$ Syaifan Nur, Filsafat Mulla Șadra: Pendiri Mazhab al-Hikmah al-Muta'aliyah (Jakarta: Teraju, 2003), h. 15-16. 
bagaikan sebuah permata di dalam lembah, yang dikelilingi oleh perbukitan dengan gunung-gunung yang menjulang di cakrawala. Di Kahak, Șadra belajar hidup asketis dengan melakukan pelatihan-pelatihan spiritual, dikr dan fiqr. Baginya, dengan melakukan pelatihan semacam ini hidupnya menjadi tercerahkan. Dengannya dia berharap mengalihkan persoalan-persoalan metafisika dari olah intelektual murni kepada olah spiritual dengan pandangan secara langsung demi mendapatkan rahasia-rahasia ketuhanan (al-hikmah ilāhiyyah) dan kebenaran mistis.

Banyak persepsi dari para penulis sejarah filsafat berkaitan dengan alih kecenderungan yang dilakukan Șadra ini. S. Hossein Nasr melihat adanya faktor sosio-politis, yakni tekanan dari para fuqaha' sebagai akibat dikemukakannya doktrin-doktrin gnosis dan metafisik secara terbuka, di samping memang dalam diri Șadra mulai muncul keyakinan bahwa dengan spiritual exercises akan bisa beroleh hikmah, ${ }^{11}$ setelah dalam dirinya diliputi perasaan bersalah karena dia begitu bergantung pada kemampuan intelektualnya sendiri dan sering melupakan agenda penghambaan diri pada Yang Maha Kuasa. Dan ini semua hanya bisa dilakukan dengan pindah ke Kahak ${ }^{12}$ Sedangkan Fazlur Rahman mengatakan bahwa kepergiannya ke Kahak disebabkan karena ketidakpuasannya terhadap gaya hidup yang melingkupi umat Islam Isfahan, yang lebih mementingkan motif-motif lahiriyah akan gemerlapnya harta dunia dan kekuasaan. Menurut Șadra adalah salah besar jika dia melangkah pada jalan yang sama dan bertopang hanya pada kekuatan intelektualnya lebih dari sekedar menyerahkan diri begitu saja pada kehendak dan kekuasaan Tuhan dengan hati yang tulus dan murni. ${ }^{13}$

Șadra menjalani kehidupan di Kahak selama kurang lebih 10 sampai 15 tahun. Sisi kehidupan ini telah membekaskan suatu pengalaman yang benarbenar baru. Jika semula kepergiannya ke Kahak dipenuhi rasa ketidakpuasan dan patah hati, sepulang dari sana dia mendapatkan keteguhan hati dan gairah baru yang membuatnya bersemangat kembali untuk mengabdi kepada Tuhan lewat aktivitas-aktivitas intelektual dan kemanusiaan.

\footnotetext{
${ }^{11}$ Istilah hikmah di sini adalah suatu kombinasi dari gnosis atau sufisme, illuminasi, filsafat, yang bukan merupakan teologi atau filsafat yang biasa dipahami. Istilah yang lebih sesuai dalam hal ini adalah teosofi, dalam arti yang sebenarnya dan orisinal, bukan dalam pengertian menurut kelompok pseudospiritualis. Syaifan Nur, "Arti Penting Mulla Șadra dan Karakteristik Aliran Pemikirannya" dalam alJamiah, No.59/1996, h.151.

${ }^{12}$ S. Hossein Nasr, “Șadr al-Din Shirazi (Mulla Șadra)” dalam MM Syarif (ed.), History..., h. 934.

${ }^{13}$ Fazlur Rahman, Filsafat Șadra, terj. Munir A. Muin (Bandung: Pustaka, 2000), h. 4.
} 
Momentum kembalinya Șadra dari Kahak bertepatan dengan dibangun sebuah madrasah oleh gubernur Syiraz saat itu, Allajwirdi Khan, dan Șadra diminta secara khusus untuk memimpin sekolah baru tersebut.14 Selama periode ini, Șadra menjadi sosok yang produktif. Sebagian besar karya-karya pikirnya ditulis pada periode ini, di samping dia menjalani tugas utamanya sebagai pengajar. Murid-murid Șadra datang dari berbagai wilayah sampai Afrika Utara dan Tibet. ${ }^{15}$

Karya pikir terbesar Șadra adalah al-Hikmah al-Muta'āliyah fi al-Asfar al'Aqliyyah al-Arba'ah yang memaparkan tentang 4 (empat) fase perjalanan yang seharusnya dilalui manusia. Empat fase ini tampaknya mencerminkan periode kehidupannya, yaitu: 1) Perjalanan makhluk menuju Tuhan, 2) Perjalanan dengan Tuhan dalam Tuhan, 3) Perjalanan dari Tuhan menuju makhluk dengan Tuhan, 4) Perjalanan dalam makhluk menuju Tuhan.

Setelah 30 tahun kehidupannya yang diisi dengan belajar, mengajar dan menulis, Șadra melakukan perjalanan ke tanah suci dengan berjalan kaki selama 7 (tujuh) kali. Intensitas kesalehannya tidak saja meningkat tetapi dia juga menjadi pribadi yang semakin tercerahkan melalui visi spiritual selama bertahun-tahun. Sekembalinya dari perjalanan hajinya yang terakhir, dia menderita sakit di Bashrah dan akhirnya meninggal pada tahun 1050H/ 1641M.16

\section{Konsep Wujud dan Klasifikasi Wujud}

Fondasi dari keseluruhan pemikiran filsafat Șadra terletak pada konsep wujudnya. Konsep wujudnya ini bertitik tolak dari problematika besar filsafat tentang hubungan antara māhiyah (esensi) ${ }^{17}$ dan wujud (eksistensi) itu sendiri. Manakah di antara keduanya yang benar-benar riil secara fundamental, yang

\footnotetext{
${ }^{14}$ Hossein Ziai, "Mulla Șadra: His Life and Works" dalam S. Hossein Nasr dan Oliver Leaman (ed.), History..., h. 637.

${ }^{15}$ Murtadha Muttahari, Tema-tema Penting Filsafat Islam, terj. A. Rifai Hasan dan Yulian L (Bandung: Mizan, 1993), h. 48. 419.

16Madjid Fakhri, Sejarah Filsafat Islam, terj. Mulyadhi Kartanegara (Jakarta: Pustaka Jaya, 1987), h.

${ }^{17}$ Māhiyah dalam arti umum adalah menunjuk tentang sesuatu yang dengannya sesuatu yang lain itu ada, Sedangkan dalam pengertian khusus, māhiyah berkaitan dengan jawaban terhadap pertanyaan apakah itu. Dalam hal ini maka dalam pengertian umum māhiyah tidak bertentangan dengan wujud karena keduanya sama-sama ada dan berada tetapi dalam pengertian khusus, antara wujud dan mähiyah benar-benar tidaksama.
} 
berada dalam realitas eksternal, yang benar-benar konkret, lawan dari abstrak, yang ada dalam konsep pemikiran; juga manakah di antara keduanya yang substansi dan mana yang aksidensi.18

Sesungguhnya jauh sebelum Șadra, permasalahan ini telah menjadi perdebatan yang selalu marak dari masa ke masa, didiskusikan secara terusmenerus sehingga menjadi problematika akut mulai masa abad Filsafat Kuno, antara Plato dan Aristoteles, sampai masa abad Filsafat Modern, antara Rasionalisme dan Empirisme. Kondisi semacam ini juga berimbas pada tradisitradisi intelektual di dunia Islam: antara paripatetisme, gnosisisme-mistisisme, teosofi illuminasionisme, maupun teologi Islam.

Tradisi paripatetisme cenderung berpihak pada Aristotelianisme. Tradisi ini berpegang kuat bahwa wujud adalah yang prinsipil dan substansial. Dialah yang berada dalam realitas eksternal atau realitas konkret, sedangkan māhiyah hanyalah sekedar aksiden, yang berada dalam abstraksi mental. ${ }^{19}$ Antara wujud dan māhiyah berbeda sama sekali dalam keberadaannya di dunia dan masingmasing tidak harus ada secara bersamaan. Adanya gambaran mental tidak harus selalu dibarengi dengan adanya realitas eksternal. Bisa jadi manusia memiliki atau membentuk gambaran mental tentang mähiyah tetapi meragukan wujudnya yang riil, ${ }^{20}$ contoh: orang bisa memahami arti kambing berkaki tiga tetapi meragukan apakah ada di dunia atau tidak. Sedangkan tradisi teosofi illuminasionisme menyatakan bahwa wujudlah yang aksiden, dan māhiyah adalah yang prinsipil dan substansial. ${ }^{21}$ Di sinilah maka kaum illuminasionis,

${ }^{18}$ Menurut Alparslan Acikgenc sebagai mana dikutip oleh Syaifan Nur bahwa perbincangan antara māhiyah dan wujud dalam dunia pada akhirnya terpilah menjadi 2 (dua). Pertama, yang mendukung pendapat bahwa realitas yang fundamental adalah mähiyah, sedangkan wujud adalah abstraksi mental semata atau disebut dengan aliran esensialis. Kedua, yang mendukung bahwa realitas yang fundamental adalah wujud sedangkan māhiyah adalah abstraksi mental atau disebut dengan aliran eksistensialis. Aliran yang pertama akan berpihak pada pluralisme ontologis. Di antara tokoh esensialis adalah al-Farabi dan Ibn. Sina. Sedangkan aliran yang kedua berpihak pada monisme ontologis. Hampir semua para sufi yang menganut doktrin wahdah al-wujūd adalah penganut monisme ontologis ini, karena bagi mereka, satu-satunya realitas adalah wujud. Meskipun demikian tidak tertutup kemungkinan ada penganut aliran pluralis sekaligus menganut monisme, seperti pada kasus Suhrawardi, yang kemudian demikian itu diikuti Sadra, yakni penganut monisme sekaligus pluralis. Lihat dalam Syaifan Nur, Filsafat Wujud...., h. 10-11. Alparslan Acikgenc, Being and Existence In Șadra and Heidegger: A Comparative Ontology (Kuala Lumpur: ISTAC, 1993), h.1-2.

${ }^{19}$ Armahedi Mahzar, Integralisme, Sebuah Rekonstruksi Filsafat Islam (Bandung: Pustaka Salman: 2003), h. xiv.

${ }^{20}$ Syaifan Nur, Filsafat Mulla Șadra..., h. 78.

${ }^{21}$ Armahedi Mahzar, Integralisme, Sebuah Rekonstruksi Filsafat Islam, h. xv. 
yang tokoh utamanya adalah Suhrawardi disebut sebagai pendukung utama așālah al-māhiyah. ${ }^{22}$ Dalam așālah al-māhiyah, Suhrawardi memulai dari prinsip bahwa suatu perbedaan yang bersifat mental tidak berarti perbedaan secara riil, artinya dua hal yang secara konseptual bisa dibedakan satu dengan lainnya tidak harus menunjukkan bahwa keduanya juga berbeda secara konkret. Atas dasar ini, dia berpendapat bahwa perbedaan antara mähiyah dan wujud hanyalah pada tingkat analisis konseptual, sedangkan di dunia eksternal, yang konkret, bahwa keduanya merupakan satu realitas yang tunggal. Di sini dia menyatakan secara eksplisit bahwa wujud adalah satu konsep yang tidak berkaitan langsung dengan realitas eksternal. Yang berkaitan langsung dengan realitas eksternal adalah māhiyah. Jadi secara fundamental, māhiyah adalah yang riil dan ketika realitas fundamental dari māhiyah ini dikonseptualisasikan maka muncullah konsep wujud. ${ }^{23}$ Kemudian tradisi gnosisisme-mistisisme yang berpegang teguh pada prinsipalitas wujud atas māhiyah dan mengatakan bahwa wujud itu bersifat gradasional. ${ }^{24}$ Dan yang terakhir adalah teologi Islam yang hanya menyatakan bahwa realitas itu ada 2 (dua), yang mutlak dan yang nisbi, dengan jurang yang tidak terseberangi antara keduanya kecuali dengan iman yang rasional. ${ }^{25}$

Sadra awalnya setuju dengan tradisi teosofi-illuminasionisme, tetapi dalam perjalanannya dia justru menyerang tradisi ini dan membela paripatetisme. ${ }^{26}$ Memperkuat gagasannya ini, dia mengajukan beberapa argumen:

1. Setiap māhiyah berbeda dari māhiyah yang lain. Sebagai contoh esensi pohon berbeda dengan esensi kehijauan. Masing-masing māhiyah tidak memiliki kesamaan dengan lainnya. Kita hanya bisa mempredikatkan satu māhiyah pada yang lainnya jika ada realitas yang menggabungkannya. Realitas eksternal yang bisa menggabungkan antara berbagai esensi itu adalah wujud.

2. Setiap māhiyah atau esensi qua (esensi tanpa eksistensi) tidak akan dapat menimbulkan efek, kecuali dia bergandeng dengan wujud, maka yang asasi atau yang fundamental-prinsipil dan sumber efek adalah wujud bukan māhiyah.

${ }^{22}$ Syaifan Nur, Filsafat Mulla Șadra..., h. 60.

${ }^{23} \mathrm{Ibid}$, h. 60.

${ }^{24}$ Musa al-Kadzim, “Tentang Kesatuan Wujud” dalam al-Hikmah, No. 14 Vol. VI/1995, h. 87.

${ }^{25}$ Armahedi Mahzar, Integralisme, Sebuah Rekonstruksi Filsafat Islam, h. xiv.

26S. Hossein Nasr, "Sadr al-Din Shirazi (Mulla Sadra)" dalam MM Syarif (ed.), A History..., h. 943. Lihat pula dalam Fazlur Rahman, Filsafat.., h. 3. 
3. Setiap māhiyah pada dasarnya adalah netral dalam hal intensitas dan kelemahannya, prioritas, dan aposterioritasnya. Tanpa wujud maka māhiyah tidak memiliki sifat-sifat itu. Oleh karenanya jika wujud tidak dianggap prinsipil maka berarti māhiyah, yang tidak memiliki atribut sebagai sumber atribut. Hal ini tidak mungkin karena sesuatu yang tidak punya atribut tidak mungkin menjadi pemberi atribut. ${ }^{27}$

Argumen-argumen itulah menegaskan posisi Șadra sebagai pembela paripatetik meskipun pendapatnya ini tidak sama persis, khususnya dengan pemikiran Ibn Sina karena Ibn Sina menganggap bahwa wujud dari setiap benda berbeda dengan wujud benda yang lain, walaupun secara prinsipil berhubungan dalam māhiyah-nya.

Bagi Șadra, wujud adalah realitas tunggal tetapi muncul dalam gradasi yang tidak sama. Dalam menjelaskan pemikiran Șadra ini bisa meminjam konsep māhiyah al-nūr milik Suhrawardi, sebagai contoh adalah ada cahaya matahari, cahaya lampu, dan cahaya lilin. Māhiyahnya cahaya tetapi dia berwujud dengan predikat yang berbeda, artinya muncul dalam manifestasi dan kondisi yang berbeda. Wujudpun demikian dalam pandangan Șadra. Dari segi kewujudannya, semua wujud itu identik. Ada tuhan, ada manusia, ada tumbuhan. Semuanya satu wujud, satu eksistensi, dan satu realitas tetapi dengan berbagai tingkat intensitas dan manifestasi yang berbeda-beda. Wujud Tuhan lebih prior dan superior dibanding wujud manusia. Wujud manusia lebih intens dibanding wujud tumbuhan, dan seterusnya. ${ }^{28}$ Perlu dicatat bahwa gradasi ini, bagi Șadra tidak melekat pada māhiyah tetapi pada wujud. ${ }^{29}$

Untuk memperjelas bahasan di atas bisa dilihat tabel berikut:

\begin{tabular}{|l|l|l|l|l|l|}
\hline & Paripatetisme & $\begin{array}{c}\text { Illuminasion } \\
\text {-isme }\end{array}$ & Gnosisisme & $\begin{array}{c}\text { Teologi } \\
\text { Islam }\end{array}$ & \multicolumn{1}{|c|}{$\begin{array}{c}\text { Mulla } \\
\text { Șadra }\end{array}$} \\
\hline $\begin{array}{l}\text { Wujud } \\
\text { (eksistensi) }\end{array}$ & Riil & mental & Riil & Riil & Riil \\
\hline $\begin{array}{l}\text { Māhiyah } \\
\text { (esensi) }\end{array}$ & Riil & Riil & Mental & Riil & mental \\
\hline
\end{tabular}

27Jalaluddin Rakhmat, "Hikmah Muta'aliyah: Madzhab Filsafat Islam Pasca Ibnu Rusydi” dalam alHikmah, No.10, Juli-September 1993, h. 73.

${ }^{28}$ Musa al-Kadzim, "Tentang Kesatuan Wujud" dalam al-Hikmah..., h. 87-88.

${ }^{29}$ Jalaluddin Rakhmat, "Hikmah Muta'aliyah ... ", h. 79. 


\begin{tabular}{|l|l|l|l|l|l|}
\hline $\begin{array}{l}\text { Hubungan } \\
\text { keduanya }\end{array}$ & $\begin{array}{l}\text { wujud } \\
\text { mendahului } \\
\text { māhiyah }\end{array}$ & $\begin{array}{l}\text { māhiyah } \\
\text { mendahului } \\
\text { wujud }\end{array}$ & $\begin{array}{l}\text { wujud } \\
\text { mendahului } \\
\text { māhiyah }\end{array}$ & $\begin{array}{l}\text { wujud } \\
\text { mendah } \\
\text { ului } \\
\text { māhiyah }\end{array}$ & $\begin{array}{l}\text { wujud } \\
\text { mendahului } \\
\text { māhiyah }\end{array}$ \\
\hline $\begin{array}{l}\text { Struktur } \\
\text { realitas }\end{array}$ & $\begin{array}{l}\text { jenjang } \\
\text { eksistensi }\end{array}$ & $\begin{array}{l}\text { gradasi } \\
\text { esensi }\end{array}$ & $\begin{array}{l}\text { jenjang } \\
\text { esensi }\end{array}$ & $\begin{array}{l}\text { polaritas } \\
\text { mutlak } \\
\text { dan } \\
\text { nisbi }\end{array}$ & $\begin{array}{l}\text { gradasi } \\
\text { eksistensi }\end{array}$ \\
\hline
\end{tabular}

Selanjutnya wujud menurut Șadra dipetakan menjadi 3 (tiga) prinsip utama, yaitu: unity of being (wahdah al-wujūd), gradation of being (tashkīk alwujūd), principality of being (așālah al-wujūd). Kemudian ada satu prinsip lagi yang menjembatani antara 3 (tiga) wujud di atas adalah trans-substantial motion (al-harakah al-jauhariyyah). Adapun penjelasan masing-masing sebagai berikut:

\section{Unity of Being (Waḥdah al-Wujūd)}

Menurut Șadra, wujud itu satu. Sebenarnya prinsip ini dibangun atas dasar pengalaman gnosisnya tentang kesatuan wujud 30 sebagai hasil dari pembacaannya terhadap pemikiran gnosis Ibn. 'Arabīy. Dia menyatakan bahwa hanya ada satu wujud yaitu wujud Tuhan. Dalam realitas yang sesungguhnya, tidak ada yang lain yang bisa disebut ada kecuali Tuhan, adapun benda-benda lain hanyalah penampakan (tajallī) dari wujud yang satu, yang merupakan satu satunya wujud. Sadra mereformulasi prinsip kesatuan wujud melalui:

a. Wujud murni, yaitu wujud yang tidak tergantung kepada selain dirinya dan tidak terbatasi. Keberadaan wujud ini mendahului segala sesuatu yang lain, yang dia ada pada dirinya sendiri, tanpa perubahan dan pergerakan. Keberadaannya ini juga tidak bisa ditangkap lewat pengetahuan rasional maupun lewat persepsi. Wujud murni ini disebut pula wujūd lā bi sharț atau wujud yang keadaannya tanpa syarat, mengatasi setiap determinasi. Wujud ini dimiliki oleh Realitas Absolut atau Realitas Mutlak.

b. Wujud yang keberadaannya tergantung kepada selain dirinya. Dia merupakan wujud terbatas yang dibatasi oleh sifat-sifat yang merupakan tambahan pada dirinya dan disifati oleh penilaian-penilaian yang bersifat terbatas. Pada tingkatan kedua ini disebut wujüd bi sharț al-shai', yang

${ }^{30}$ S. Hossein Nasr, "Mulla Șadra: His Teachings", dalam S. Hossein Nasr dan Oliver Leaman (ed.), History..., h. 647. 
berkaitan dengan keadaan wujud kosmis, yang tersusun secara hierarkhis dari yang superior menuju yang prior, dari yang tidak terbatas menjadi yang terbatas, dari yang rohani menjadi yang materi.

c. Wujud absolut dalam penyebarannya, yang generalitasnya jangan dikaburkan dengan universalitasnya sebab wujud adalah aktualitas yang murni, sedangkan konsep universal berada dalam potensialitas, yang membutuhkan sesuatu yang ditambahkan kepadanya agar dia menjadi aktual dan konkret. ${ }^{31}$

Realitas heterogenitas segala sesuatu datang dari wujud bukan dari māhiyah-nya. Wujud tidak dapat didefinisikan selama dia dianggap tidak mempunyai differensia, genus, aksidensia atau sifat khusus tertentu. Meskipun begitu wujud dapat dengan jelas dibedakan dari māhiyah sehingga objek penciptaan Tuhan bukanlah māhiyah tetapi wujud, dan Tuhan adalah wujud yang absolut ${ }^{32}$ Kerangka bangun unity of being dari Șadra ini jelas khas, berbeda dengan 2 (dua) tradisi sebelumnya, yakni tradisi paripatetisme dan tradisi illuminasionisme.

Kerangka bangun unity of being, ketunggalan atau kesatuan wujud dalam pemikiran Șadra inilah yang membentuk sifat terdalam. Pada posisi luar, konsep itu hanya ada gradasi dan variasi. Maka bagi Șadra, wujud adalah kesatuan dalam keanekaragaman dan keanekaragaman dalam kesatuan (unity in multiciplity dan multiciplity in unity). ${ }^{33}$ Dengan cara ini, Șadra berupaya menyintesiskan berbagai pandangan tentang prinsip metafisika yang paling dalam dan paling tersembunyi, tetapi juga paling nyata. Dia berusaha menunjukkan bahwa sesungguhmya wujud benar-benar esa, namun pelbagai determinasi dan cara-cara memandangnya menyebabkan manusia memahami keberanekaragaman, yang menutupi keesaan-Nya. Akan tetapi bagi mereka yang memiliki visi spiritual, prinsip kesatuan wujud ini justru merupakan kebenaran yang paling nyata dan terbukti, sedangkan keanekaragaman tersembunyi darinya. Sesungguhnya keyakinan kebenaran yang demikian jelas tidak merupakan produk pembahasan diskursif dan rasional, melainkan berdasarkan pada pengalaman spiritual, melalui mujāhadah dalam waktu yang lama dan karunia Tuhan.

\footnotetext{
31Syaifan Nur, Filsafat Mulla Șadra..., h. 103-108.

32Dudun S. Khudri, “Mulla Șadra, Metafisikawan Muslim Terbesar dari Safawi” dalam Republika, 6 September 2000.

${ }^{33}$ S. Hossein Nasr, “Sadr al-Din Shirazi (Mulla Șadra)” dalam MM Syarif (ed.), History..., h. 944.
} 


\section{Gradation of Being (Tashkīk al-Wujūd)}

Ide tentang gradation of being memiliki sejarah panjang, baik dalam tradisi paripatetisme maupun dalam tradisi illuminasionisme, khususnya dalam pemikiran Suhrawardi, sebelum akhirnya diterima Șadra dengan perubahan besar yang memunculkan pemaknaan baru.

Șadra menerapkan konsep gradasi ini pada wujud, bukan pada māhiyah seperti yang telah dilakukan oleh Suhrawardi. Berkaitan dengan gradasi wujud, Șadra menegaskan bahwa wujud adalah single reality tetapi muncul dengan gradasi dan derajat intensitas eksistensi yang berbeda. ${ }^{34}$ Dengan kata lain bahwa wujud itu tunggal, hanya saja manifestasinya bervariasi sesuai dengan tingkat intensitasnya. Setiap wujud mengalami kebertahapan, penurunan, dan kebertingkatan dari wujud yang suci dan murni, dari Tuhan sebagai wujud yang paling tinggi sampai ke prime matter sebagai wujud yang rendah.

Implikasi dari prinsip gradasi wujud sebagaimana di atas meniscayakan bahwa wujud akan selalu berpartisipasi dalam satu susunan gradasi dan hierarkhi, mulai dari wujud Tuhan sampai pasir di pantai. Dari sini Șadra telah berhasil memberikan solusi, memoderasi bagaimana muncul dari sesuatu yang satu dalam bentuk realitas yang heterogen dan multi stratifikasi.

\section{Principality of Being (Așālah al-Wujūd)}

Kaum paripatetik dan gnosis meski menyatakan wujud sebagai yang prinsipil, tetapi mereka menegaskan adanya perbedaan antara satu wujud dengan lainnya melalui māhiyah-nya. Berbeda dengan Șadra yang mengatakan bahwa wujud adalah sesuatu yang prinsipil dan dia adalah realitas tunggal (single reality). ${ }^{35}$ Wujud tidaklah dapat ditangkap oleh pikiran. Pencapaiannya hanya bisa disaksikan secara langsung melalui intuisi. Sementara māhiyah menjadi batas ujung dan bayangan wujud. Dengan demikian, dalam pandangan Șadra, keberadaan māhiyah hanya sebagai batas, tepian atau bayangan sehingga dia tidak memiliki realitas yang independen. Keberadaannya bergantung pada sesuatu yang lain, yakni wujud. Karenanya juga māhiyah tidak lagi menjadi fatamorgana. ${ }^{36}$ Di sinilah terlihat jelas bahwa Șadra mempunyai prinsip așālah al-wujūd, tidak aṣālah al-māhiyah.

\footnotetext{
${ }^{34} \mathrm{Ibid}, \mathrm{h} .943$.

${ }^{35}$ Syaifan Nur, Filsafat Mulla Șadra...., h. 89.

36Jalaluddin Rakhmat, “Hikmah Muta’aliyah ...”, h. 79-80.
} 


\section{Trans-Substansial Motion (Harakah al-Jauhariyyah)}

Satu hal yang menarik pada pandangan Șadra ini adalah pandangannya tentang gerak substantif atau trans-substansial motion (harakah al-jauhariyyah) yang berbicara tentang terjadinya perubahan tingkat wujud atau eksistensi pada benda-benda lain dalam rangka tashkik al-wujūd. Berbeda dengan pemikiran filosofis sebelumnya yang menganggap substansi sebagai sesuatu yang tetap, dalam pandangan Șadra bahwa substansi bisa berubah-ubah, batu dimungkinkan menjadi tanaman, tanaman menjadi hewan, dan seterusnya yang sekarang dikenal dengan pandangan evolusionisme. Berbeda dengan evolusionisme, gerak evolusi Șadra bukanlah perubahan-perubahan materi yang bersifat acak dan akibat dari seleksi alam seperti pandangan evolusi Darwin. Bagi Șadra, evolusi merupakan perubahan substantif menuju tingkat wujud yang lebih tinggi karena tarikan wujud tertinggi yaitu Tuhan. Dalam bahasa filosofis kontemporer dapat dikatakan bahwa pandangan evolusi Șadra sebagai pandangan teleologis yang mengikuti asas finalitas, artinya bahwa dalam gerak perubahan ini pasti menuju pada tujuan tertentu dan pada akhirnya memasuki wilayah atau sisi-sisi spiritual yang sangat penting. Istilah lain bahwa seluruh wujud atau eksistensi di dunia bergerak menuju kesempurnaan, yang tujuan dan akhirnya adalah mencapai kemajuan di bidang spiritualitas.

Prinsip ini muncul sebagai konsekuensi logis dan merasionalisasikan prinsip-prinsip wujud sebelumnya, yaitu dari ketunggalan atau kesatuan wujud (waḥdah al-wujūd), gradasi wujud (tashkikk al-wujūd), dan prinsipalitas wujud (asālah al-wujūd). Prinsip ini pada akhirnya telah memberi kontribusi solusi dalam tradisi Islam terhadap persoalan-persoalan tradisional dan debat teologis tentang penciptaan selama sembilan abad sebelumnya, yakni antara filosof, Ibn. Rusyd, dan mutakallim, al-Ghazali, tentang problem qadìm atau hadìth-nya alam. 37

Akhirnya yang paling penting dalam hal ini adalah Șadra telah menempatkan seluruh bidang wujud di atas dalam gerak yang terus-menerus dengan mengatakan bahwa gerak tidak hanya pada kualitas-kualitas sesuatu, tetapi juga pada subtansinya. Ajaran tentang gerak substansi (harakah aljauhariyyah) adalah merupakan orisinalitas pemikiran Șadra yang memberi

${ }^{37}$ S. Hossein Nasr, "Mulla Șadra: His Teachings"dalam S. Hossein Nasr dan Oliver Leaman (ed.), History..., h. 649. 
kontribusi besar bagi perkembangan filsafat Islam. Dari sini Șadra telah mengubah gradasi ala Suhrawardi yang pas ke dalam prinsip tashkik .

\section{Struktur Logika dalam Konsepsi Wujud}

Warisan khasanah intelektual Șadra yang paling penting dalam sepanjang perjalanan filsafat, khususnya filsafat Islam, adalah pemikiran sistem ontologismmetafisisnya yang bermula dari penyelidikan tentang wujud sebagaimana dijelaskan di atas. Penjelasan singkat sebelumnya bahwa wujud dalam pandangan Șadra adalah satu-satunya konstituen realitas dalam dunia eksternal, sehingga wujud itu identik dengan realitas itu sendiri. Sedangkan māhiyah adalah konstruksi mental. Realitas segala sesuatu datangnya dari wujud, bukan dari māhiyah sehingga tidak wujud tergantung pada māhiyah, tetapi justru māhiyah sangat tergantung pada wujud. Istilah dalam logika bahwa wujud berada dalam posisi jins atau genus, bukan fasl atau differentia yakni sifat pembeda. ${ }^{38}$

Berangkat dari konsep wujud, Șadra membangun prinsip-prinsip ketunggalan atau kesatuan wujud, gradasi wujud, prinsipalitas wujud, dan gerak substansial. Prinsip-prinsip tersebut saling berkait, masing-masing berkarakter eksistensial, dinamis, holistik, dan sistemik. Prinsip ketunggalan atau kesatuan wujud dan prinsipalitas wujud merupakan landasan utama filsafat wujud Șadra yang niscaya mempunyai implikasi logis terhadap penolakan atas adanya dualitas antara wujud dan māhiyah, karena māhiyah muncul hanya jika ada wujud. Māhiyah adalah batasan wujud. Dengan demikian keberadaan duaduanya tidaklah bisa dipecah-pecah kecuali jika pemecahan itu hanya hadir dalam pikiran. ${ }^{39}$ Kemudian prinsip gradasi wujud merupakan pola pikir yang disiapkan untuk memediasi antara entitas-entitas di dunia yang dalam kenyataannya heterogen (multiplicity) dengan prinsip ketunggalan atau

\footnotetext{
${ }^{38}$ Ingat 5 (lima) konsep universal atau kulliyah al-khamsah dalam logika, yaitu: 1) jins atau genus adalah term yang mempunyai bawahan yang banyak dan berbeda-beda tetapi kesemuanya mempunyai sifat yang sama dan mengikat keseluruhan bawahan yang berbeda-beda, 2) fasl atau differentia yaitu sifat pembeda, term yang membedakan satu hakikat dengan hakikat yang lain yang sama-sama terikat dalam satu jins atau genus, 3) nau' atau spesia yaitu term yang menunjukkan pada kelas klasifikasi, 4) khassah atau propria yaitu term yang menyatakan sifat hakikat dari suatu nau' atau spesia sebagai akibat dari sifat pembeda yang dimilikinya, 5) 'aradh atau accidensia adalah term yang menunjukkan sifat yang tidak harus dimiliki oleh satu nau' atau spesia. Lihat dalam Mundiri, Logika Oakarta: Raja Grafindo Persada, 1998), h.24-26.

${ }^{39}$ Fazlur Rahman, The Philosophy of Mulla Sadra (Albany: State University of New York Press, 1975), h. 33.
} 
kesatuan wujud (unity) yang Șadra kedepankan. Dalam memecahkan dua sisi yang tampaknya akan mengakibatkan ketakkonsistenan dalam pemikirannya ini, dia justru memposisikan heterogenitas entitas yang bertebaran di dunia di dalam kesatuan wujud melalui prinsip gerakan substansial. Berdasarkan dari sinilah maka ontologi Șadra memasuki sistem yang berbasis eksistensial, ada perubahan yang dinamis, dan bersifat holistik.

Dalam perspektif tersebut maka terbangun implikasi logika dalam klasifikasi wujud Șadra sebagai berikut:

\begin{tabular}{|l|l|l|}
\hline \multicolumn{1}{|c|}{ Kontribusi } & \multicolumn{1}{|c|}{ Klasifikasi Wujud } & \multicolumn{1}{|c|}{ Implikasi Logika } \\
\hline \multirow{2}{*}{$\begin{array}{l}\text { Ontologi } \\
\text { Sadra }\end{array}$} & Kesatuan wujud (waḥdah al-wujūd/ unity of being) & Ontologi holistik \\
\cline { 2 - 3 } & $\begin{array}{l}\text { Gradasi wujud (tashkīk al-wujūd/gradation of } \\
\text { being) }\end{array}$ & $\begin{array}{l}\text { Pluralitas dalam } \\
\text { kesatuan }\end{array}$ \\
\cline { 2 - 3 } & $\begin{array}{l}\text { Prinsipalitas wujud (așālat al-wujūd/ principality of } \\
\text { being) }\end{array}$ & Ontologi eksistensial \\
\cline { 2 - 3 } & $\begin{array}{l}\text { Gerak substansial (harakah al-jauhariyyah/trans- } \\
\text { substantial motion) }\end{array}$ & $\begin{array}{l}\text { Gerakan menuju } \\
\text { kesatuan dinamis }\end{array}$ \\
\hline
\end{tabular}

Pencapaian ontologi yang holistik pada pemikiran wujud Șadra mempertegas peniadaan dan penolakan terhadap paradigma dan logika dualitas yang berciri oposisi binair, yang mempertentangkan antara dua hal, seperti: jiwatubuh, tuhan-manusia, esensi-eksistensi, subjek-objek, benar-salah, dan seterusnya. Sifat holistik artinya cara pandang yang menyeluruh dalam mempersepsi wujud sebagai realitas, dengan penekanan pada interrelasi, interkoneksi, dan interdependensi segala sesuatu dalam sebuah net (jaringan), yang bercorak sistemik, integrasi, dinamis, non-mekanistik, dan non-linier. Pandangan holistik ini membangun stressing segala sesuatu atas landasan keseluruhan sebagai kesatuan, tidak bagian-bagian. ${ }^{40}$ Dalam konteks tersebut yang kemudian perlu diingat bahwa prinsip pertama dan utama dalam klasifikasi wujud adalah ketunggalan atau kesatuan wujud, meski pada hal tersebut berangkat dan terbangun wujud yang bermacam-macam yang kesemuanya bergerak menuju kesatuan dinamis.

${ }^{40}$ Husain Heriyanto, Paradigma Holistik: Dialog Filsafat, Sains, dan Kehidupan Menurut Sadra dan Whitehead (Bandung: Teraju, 2003), h. 12. 
Pencapaian sifat holistik dalam ontologi Șadra akan memunculkan kehidupan yang sehat, yang berangkat dari logika atau nalar yang sehat. ${ }^{41}$ Hidup sehat dalam hal ini tidak hanya sehat dalam pengertian bebas dari penyakit fisik, tetapi juga terbebas dari penyakit mental, juga sosial. Sedangkan logika atau nalar yang sehat dimaksud adalah suatu sistem dan struktur logika yang berada dalam kondisi kefinalan intrinsik, perampungan, pemenuhan, dan kedamaian batin yang kompatibel dengan aktivitas yang sangat intens; sebuah pengertian unik akan kesatuan, kemenyeluruhan, dan persatuan dengan tanpa pemisahan mutlak antara objek dan subjek; suatu penangguhan tertentu dari persepsipersepsi biasa kita atas ruang dan waktu dimana alam dilibatkan; suatu visi dari semua wujud sebagai yang hidup secara esensial dalam suatu cara yang sangat berbeda dengan pemisahan atas entitas yang bernyawa dan tidak bernyawa; suatu pemahaman kebebasan dan pembebasan batin terdalam yang secara negatif dinyatakan dengan tiadanya rasa khawatir, perasaan bersalah, penyesalan; suatu persepsi universal, cinta atau sayang yang tidak ternilai yang meluas pada seluruh wujud, dan seterusnya. Inilah yang disebut dengan logika atau nalar transendensi. ${ }^{42}$

Logika atau nalar transendensi sebagai implikasi berpikir wujud versi Șadra menegaskan adanya tipe nalar lain dalam filsafat Islam di luar nalar paripatetik pengaruh Aristoteles yang bersifat analitis (linier), yang beroperasi melalui silogisme, penguraian premis-premis dan penyimpulan akibat-akibat ikutannya. Apabila digunakan untuk melihat alam akan dijabarkan dengan tepat melalui aksioma-aksioma dasar sistem dan akibat logisnya. Dalam filsafat Islam mengenal nalar yang bersifat sintesis (circular), yang memadukan segenap unsur realitas ke dalam kesatuan ketimbang memilah-milahnya menjadi aksioma, premis, penyimpulan dan pola-pola yang seperti itu bersifat melingkar mengikuti lingkaran realitas. ${ }^{43}$

\footnotetext{
${ }^{41}$ Istilah "Sehat" dalam konteks ini berangkat dari pengertian dalam kamus Webster's New Unabridged English Dictionary (New York: Barbes \& Noble, 1989) disebutkan bahwa istilah heal (Penyembuhan) dan health (Kesehatan) secara etimologis memiliki akar kata yang sama dengan whole (keseluruhan). Whole (keseluruhan) sama dengan pengertian holistik. Hal ini mengindikasikan bahwa paradigma holistik berarti cara pandang yang sehat, berpikir holistik artinya berpikir yang sehat. Atau dapat diartikan bahwa sembuh dan hidup sehat sebagai manusia. Ibid, 24.

${ }^{42}$ James Winston Morris, Mulla Șadra: Kearifan Puncak, terj. Dimitri Mahayana dan Dedi Djuniardi (Yogyakarta: Pustaka Pelajar, 2001), h. 10.

${ }^{43}$ Oliver Leaman, Pengantar Filsafat Islam: Sebuah Pendekatan Tematis, terj. Musa Kadzim dan Arif Mulyadi (Bandung: Mizan, 2001), h. 181.
} 
Implikasi logis cara berpikir Șadra akan memunculkan sebuah grand theory yaitu unity in multiciplity and multiciplity in unity, artinya kesatuan dalam keberanekaragaman dan keberanekaragaman dalam kesatuan. Gerakan bolak balik ini, upaya menjembatani antara wujud sebagai realitas eksternal yang heterogen atau beraneka ragam dan yang fundamental dengan māhiyah sebagai realitas mental, melalui sebuah gerakan substansial dengan proses illuminasi.

\section{Nalar Transendensi Meretas Radikalisme Beragama}

Grand theory kesatuan dalam keberanekaragaman dan keberanekaragaman dalam kesatuan sebagaimana disampaikan di atas diderivasi dari sebuah kondisi yang heterogen. Kondisi heterogen tidak menjadi medan pengabsahan keperbedaan tetapi lewat pencerapan individual dan ketajaman intuisi justru akan memperoleh kesadaran akan heterogenitas. Di sini Șadra ingin menawarkan satu pemaknaan baru lewat analisis filosofis-metafisik terhadap wacana cara berada atau cara bereksistensi yang ideal di tengah realitas heterogenitas. Seluruh entitas agama, budaya, dan pemikiran, seberapa banyak variasinya terwadah oleh suatu eksistensi yang tunggal yang bersifat universal. Partikularitas budaya tetap diakui eksistensinya sebagai representasi dari realitas yang sama tetapi dengan tingkat gradasi yang beda. Dalam konteks ini Șadra menegaskan bahwa universalitas bentuk alam semesta mengatasi seluruh prime matter partikularitasnya. Sebagai manifestasi dari realitas mutlak maka seluruh wujud, tanpa membedakan yang bersifat mental maupun realitas empiris, terbingkai dalam frame unity.

Konstruksi pemikiran semacam itu menjadi penting dalam pemikiran Islam pada umumnya. Dalam tataran teoritis, kehadirannya telah membuka rantairantai belenggu dan menembus tembok-tembok pemisah antara satu disiplin keislaman tertentu dengan disiplin keislaman lainnya, yang selama berabadabad terpisah secara tajam. Dalam tataran praktis, konstruksi pemikiran ini akan berkontribusi dalam mengatasi hambatan atau keterbatasan hubungan yang disebabkan perbedaan keyakinan, agama, mazhab beragama, budaya, dan seterusnya, melalui daya transendensinya, sehingga patut dipertimbangkan untuk dijadikan model atau tipe ideal pemikiran Islam dewasa ini dan di masa yang akan datang. Apalagi jika dipertimbangkan lebih jauh mengenai wataknya yang senantiasa memelihara dan melatih kecerdasan intelektual melalui kesucian jiwa, dengan berusaha menghindari motif-motif dan tujuan-tujuan jangka pendek atau yang bersifat keduniaan, dalam pencarian kebenaran. 
Dengan demikian maka tampak nyata bahwa filsafat adalah hasil refleksi mendalam tentang kondisi yang ada. Adalah salah jika ada persepsi bahwa filsafat hanya berkaitan dengan aktivitas perenungan saja, yangmana para filosofnya berasyik-mansyuk hanya untuk memuaskan rasionalitasnya sendiri. Perlu diingat dalam perjalanan munculnya filsafat bahwa filsafat sokrates adalah hasil dari kegelisahannya menghadapi kaum sophis, dan perlu dicatat pula bahwa filsafat Șadra dalam hal ini juga berangkat dari visi komprehensif perjalanan hidupnya dan tidak steril terhadap milieu yang mengitari kehidupannya, yang pada akhirnya bisa memberikan sumbangan pada dimensidimensi kemanusiaan nyata.

Produk pemikiran filsafat Șadra merupakan titik balik (a turning point) karakteristik dan setting Isfahan yang plural, yang rentan dengan kerancuan dan ketegangan, sehingga dibutuhkan tradisi intelektual baru yang sifatnya bisa mengharmonisasikan tradisi yang berbeda tetapi dengan tetap tidak menghilangkan ciri dari masing-masing tradisi yang ada.

Sebagai respon atas setting yang demikian maka lahirlah perkembangan dinamis nalar baru yang sama sekali meninggalkan logika dualistik. Berangkat dari kecerdasan interpersonal dan kemampuan appropriasi Șadra, dia mentransendensi eksistensi tradisi-tradisi yang telah ada. Transendensi tradisi yang dimaksud Șadra di sini tidak berarti meluluhkan sama sekali unsur dari masingmasing tradisi. Masing-masing tradisi tetaplah diakui adanya, keberadaannya, dan perbedaannya, meskipun keberadaan dan perbedaan tersebut tidaklah boleh dijadikan sebagai medan pengabsahan munculnya klaim kebenaran (truth claim).

Jika logika ini diterapkan dalam suasana kehidupan yang heterogen, khususnya heterogenitas agama dan keyakinan maka akan menghasilkan model keberagamaan plural. Model keberagamaan ini tidak bermaksud akan mereduksi macam-macam agama menjadi satu. Keberagamaan plural mengidealisasikan macam-macam agama berkoeksistensi dan berproeksistensi, berdiri sama tinggi dan duduk sama rendah. Yang diinginkan dalam keberagamaan plural adalah more than sheer acknowledgment of plurality and mere wishful thinking of unity.44 Berkaitan dengan pemikiran ini kiranya

44Raimundo Panikkar, "Four Attitudes", dalam Gary E. Kessler (ed.), Philosophy of Religion (California: Wadsworth, 1999), h. 535. 
mengingatkan kita pada sketsa yang dibuat oleh Huston Smith, ahli agamaagama, sebagaimana dikutip oleh Budhy Munawar Rachman: 45

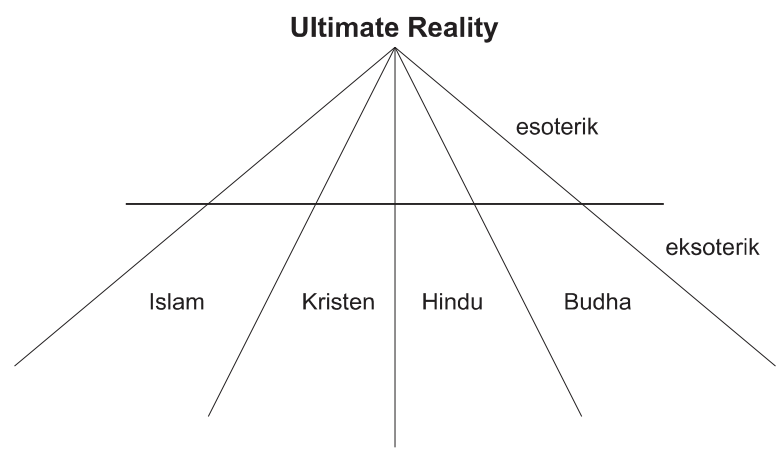

Dalam sketsa ini terlihat bahwa pada dasarnya tidaklah penting perbedaan antar agama, meskipun perbedaan antar agama memang realitas eksternal yang tidak bisa kita elakkan. Dalam pandangan ini, perbedaan yang penting bukanlah antara agama-agama, tetapi antara orang-orang dalam setiap agama. Mereka yang bisa memahami apa yang ada di atas garis, yaitu segi kesatuan transendensi agama-agama, dapat diidentifikasi sebagai seorang esoterik. Orang esoteris ini mempunyai pola keberagamaan mistis, yang berafiliasi pada keilmuan tasawuf. Mereka itu, yang berasal dari berbagai macam agama, sadar bahwa nereka secara ultime ada dalam kesatuan dengan pemeluk agama-agama lain, karena seluruhnya datang dari dan akan kembali kepada yang ilahi.

Selanjutnya mereka yang berada di bawah garis, dapat diidentifikasi sebagai seorang eksoteris. Orang eksoteris mempunyai pola keberagamaan normatif. Mereka mempunyai pandangan keagamaan yang menganggap agama sendiri sebagai kebenaran final. Agamanya sendiri adalah absolut, justru karena membawa kebenaran itu.

Di sinilah model keberagamaan plural sebagai implikasi sistem dan struktur logika dalam klasifikasi wujud Șadra menemukan momentum dan makna signifikansinya di tengah arus dan dinamika tatanan dunia yang saat ini berkembang menuju tatanan yang global. Menuju tata kehidupan dunia baru

${ }^{45}$ Budhy Munawar Rachman, Islam Pluralis: Wacana Kesetaraan Kaum Beriman Oakarta: Paramadina, 2001), h. 521. 
yang ideal berbasis pluralitas, heterogenitas meniscayakan keharusan adanya sistem tata hubungan baru inter cultural, inter faith yang solid. Dalam perspektif Sadra, orang-orang esoteris merefleksikan prinsip ketunggalan atau kesatuan wujud (unity of being/wah̆dah al-wujūd), sedangkan orang-orang eksoteris merefleksikan prinsipalitas wujud atau eksistensi (principality of being/așālah al-wujūd) yang beraneka ragam sebagai akibat gradasi wujud (gradation of being/tashkikk al-wujūd). Orang-orang esoteris dalam situasi dan kondisi tertentu membutuhkan kepastian (certainty) posisinya di antara agama-agama lain, sehingga suatu saat mereka bisa menjadi eksoteris. Sebaliknya orang-orang eksoteris pada suatu saat harus mampu menjadi esoteris. Gerakan dari esoteris menjadi eksoteris dan sebaliknya, dari eksoteris menjadi esoteris ini terefleksikan dengan gerakan substansial (trans-substantial motion/harakah aljauhariyyah).

Nalar atau logika transendensi Șadra menghasilkan grand theory yaitu unity in multiciplity and multiciplity in unity. Jika grand theory ini ditubuhkan dalam cara pandang di tengah heterogenitas agama maka akan mengimplikasikan model keberagamaan plural. Selanjutnya model keberagamaan ini akan menumbuhkan nalar, sikap, dan perilaku yang welcome terhadap pihak lain. Jika yang semacam ini menjadi nalar berpikir dan berperilaku setiap manusia yang niscaya hidup di tengah heterogenitas maka tindak radikal, konflik, kekerasan, teror akan dapat diretas dengan sendirinya, termasuk yang mengatasnamankan agama.

\section{E. Kesimpulan}

Dari uraian di atas, jawaban-jawaban atas ketiga persoalan bisa disimpulkan sebagai berikut:

Pertama, wujud menurut Mulla Șadra adalah sesuatu yang paling fundamental dalam realitas eksternal. Dia datang mendahului māhiyah. Māhiyah ini berupa realitas mental. Dari sini dia membangun prinsip eksistensinya menjadi prinsipalitas wujud yang berarti wujudlah yang utama dan pertama sehingga menempatkan Șadra pada pihak existentialism ontologism; lalu ketunggalan atau kesatuan wujud yang berarti wujud adalah satu. Meski satu, dalam realitas eksternalnya wujud atau eksistensi itu beranekaragam dan bergradasi, menjembatani yang satu dan ragam dibangunlah prinsip gerakan substansial. 
Kedua, konsep wujud yang demikian akan menghasilkan logika atau nalar transendensi. Logika atau nalar ini tidak membangun logika yang berrelasi kausalitas dan korespondensif. Dia berrelasi erat dengan logika illuminatif. Ini akan berimplikasi logis pada penafian binair opposition yang dualistik, yang tidak jarang menumbuhkan nalar konflik dan eksklusif serta sikap dan perilaku intoleransi. Dengan cara pikir demikian yang konkretnya bisa dianalogikan bagai hubungan antara sinar matahari yang melimpah dengan matahari itu sendiri maka lahirlah teori Șadra yakni unity in multiplicity and multiplicity in unity. Teori inilah yang melahirkan nalar beragama plural. Apabila nalar plural diaplikasikan dalam proses keberagamaan maka akan menghasilkan model keberagamaan plural. Kemudian jika model keberagamaan plural yang bernalar plural ini disosialisasikan dan menjadi habit of mind di antara umat beragama dan dipraktekkan dalam kehidupan keberagamaan maka realitas heterogenitas keberagamaan tidak lagi menjadi ancaman penyebab ketegangan, konflik, dan disintegrasi.]

\section{DAFTAR PUSTAKA}

Acikgenc, Alparslan, Being and Existence in Șadra and Heidegger: A Comparative Ontology, Kuala Lumpur: ISTAC, 1993.

Fakhry, Madjid, Sejarah Filsafat Islam, terj. Mulyadhi Kartanegara, Jakarta: Pustaka Jaya, 1987.

Heriyanto, Husain, Paradigma Holistik: Dialog Filsafat, Sains, dan Kehidupan Menurut Șadra dan Whitehead, Bandung: Teraju, 2003.

al-Jābiri, Muḥammad 'Ābid, Takwīn al-'Aql al-'Arabī, Beirut: al-Markaz al-Șaqafi al'Arabī, 1991.

al-Kadzim, Musa, "Tentang Kesatuan Wujud" dalam al-Hikmah, No. 14 Vol. $\mathrm{VI} / 1995$.

Kessler, Gary E. (ed.), Philosophy of Religion, California: Wadsworth, 1999.

Khudri, Dudun S., "Mulla Șadra, Metafisikawan Muslim Terbesar dari Safawi" dalam Republika, 6 September 2000. 
Leaman, Oliver, Pengantar Filsafat Islam: Sebuah Pendekatan Tematis, terj. Musa Kadzim dan Arif Mulyadi, Bandung: Mizan, 2001.

Mahzar, Armahedi, Integralisme, Sebuah Rekonstruksi Filsafat Islam Bandung: Pustaka Salman: 2003.

Morris, James Winston, Mulla Șadra: Kearifan Puncak, terj. Dimitri Mahayana dan Dedi Djuniardi, Yogyakarta: Pustaka Pelajar, 2001.

Mundiri, Logika, Jakarta: Raja Grafindo Persada, 1998.

Muttahhari, Murtadha, Tema-tema Penting Filsafat Islam, terj. A. Rifai Hasan dan Yulian L., Bandung: Mizan, 1993.

Nasr, S. Hossein, Oliver Leaman (ed.), History of Islamic Philosohpy, Part I, London and New York: Routledge, 1996.

Nur, Syaifan, "Arti Penting Mulla Șadra dan Karakteristik Aliran Pemikirannya" dalam al-Jami'ah, No. 59/1996.

“Tradisi Intelektual di Kawasan Persia: Melacak Setting Historis Pemikiran Mulla Șadra” dalam Esensia, Vol.3, No.1, Januari 2002. Filsafat Mulla Șadra: Pendiri Mazhab al-Hikmah al-Mutaaliyah, Jakarta: Teraju, 2003.

Filsafat Wujud Mulla Șadra, Yogyakarta: Pustaka Pelajar, 2002.

Rachman, Budhy Munawar, Islam Pluralis: Wacana Kesetaraan Kaum Beriman, Jakarta: Paramadina, 2000.

Rahman, Fazlur, Filsafat Șadra, terj. Munir A. Muin, Bandung: Pustaka, 2000.

The Philosophy of Mulla Sadra, Albany: State University of New York Press, 1975.

Rakhmat, Jalaluddin, "Hikmah Mutaaliyah: Madzhab Filsafat Islam Pasca Ibnu Rusydi" dalam al-Hikmah, No.10, Juli-September 1993.

Syarif, MM (ed.), History of Muslim Philosophy, Weisbaden: OttoHarrasowitz, 1963.

Yazdi, Mehdi Ha'iri, Ilmu Hudhuri: Prinsip-Prinsip Epistemologi dalam Filsafat Islam dari Suhrawardi Via Wittgenstein, terj. Ahsin Mohammad, Bandung: Mizan, 1996. 
